\title{
IVAN THE TERRIBLE TO PETER THE GREAT: BRITISH FORMATIVE INFLUENCE ON RUSSIA'S MEDICO-APOTHECARY SYSTEM
}

\author{
by
}

\author{
JOHN H. APPLEBY*
}

"THE part played by Englishmen in the introduction and improvement of the medical art in Russia could hardly be overestimated"; so wrote W. J. Bishop over fifty years ago in a paper about English physicians in sixteenth- and seventeenth-century Russia. ${ }^{1}$ Indeed, from the founding at Moscow in 1581 of the first Court Pharmacy by an Englishman, to the reorganization of the Apothecaries' Chancery by a Scotsman at the time of the capital's transfer to St Petersburg, British doctors and apothecaries performed a key role in shaping and developing Russia's medico-apothecary system.

A crucial factor was the economic one of the Russia, or Muscovy, Company, incorporated by Royal Charter in 1555 following Richard Chancellor's voyage in 1553 to Archangel in an endeavour to discover a north-east passage to India or Cathay. The fifteenth century had seen the rise of the Muscovy state, with the transfer of the central government to Moscow, whose ruler Ivan the Terrible (1533-84), embroiled in wars with Russia's hereditary western enemies (Poland, the Teutonic knights, and Sweden), wished to develop his one free outlet to the west, through Archangel. Therefore, in return for military and technical experts and materials, he granted the Russia Company very advantageous trading rights and exemptions. ${ }^{2}$

Osip Nepea, Russia's first ambassador to England, returned to Ivan's court in 1557, aboard a ship loaded with war materials and accompanied by several experts, particularly in medicine and mining, commodities in which Russia long continued dependent on foreign supply. The specialists included Dr Ralph Standish, a Cambridge graduate, the apothecary Richard Elmes, and the Dutch apothecary Arend Claesen van Stellingswerfft. Standish, the first doctor in Russia, may have died there two years later, but Richard Elmes, the earliest English apothecary at the Russian court, stayed for twenty-seven years, until 1584.

A further expansion occurred in 1567, when ships carrying over the apothecary Thomas Carver and Dr Reynolds, also brought two chests of apothecary wares; ${ }^{3}$ the

* John H. Appleby, MA, PhD, 51 College Road, Norwich, Norfolk NR2 3JP.

This paper is partly based on the 1982 Gideon Delaune Lecture given to the Faculty of the History of Medicine and Pharmacy of the Society of Apothecaries under the title 'Ivan the Terrible to Catherine the Great - British doctors, apothecaries, and medicine in Russia'.

' W. J. Bishop, 'English physicians in the sixteenth and seventeenth centuries', Proc. R. Soc. Med., 1929, 23: 144.

${ }^{2}$ Sir Bernard Pares, A history of Russia, London, Jonathan Cape, 1958, p. 135.

${ }^{3}$ Professor Wilhelm Richter, the eminent Russian medical historian, rightly stressed that the development of medicine in Russia was largely due to the establishment of the sea route by the English and their 


\section{J. H. Appleby}

Tsar made additional concessions to the Russia Company whereby it gained a monopoly of all trade by the White Sea over other English and foreign merchants, and permission to trade from Russia to Persia and Cathay. English factories were built at Archangel, Vologda, Narva, and Moscow. In the next year, at Ivan's personal request, Queen Elizabeth sent him another doctor and another apothecary - the Belgian doctor Arnold Lindsay, famous in his day for his books on medicine and mathematics, and his brother Jacob. Both Dr Lindsay and Thomas Carver died when the Crimean Khan and his Tartars sacked Moscow in 1571.4

Although practically nothing is known about the activities of these apothecaries and doctors, the mere fact that Ivan the Terrible repeatedly asked Elizabeth for more of them demonstrates that he valued their expertise and that they supplied a real need. It was at the Tsar's request that Dr Robert Jacob and the apothecary James Frencham were engaged in 1581 together with several regimental surgeons. Frencham is generally regarded as the founder of the first Moscow Court Pharmacy - the progenitor of the Russian medico-apothecary system. Some historians of pharmacy dispute this claim, on the grounds that van Stellingswerfft, the Dutch apothecary, arrived in 1557 and served as pharmacist to the Tsars for forty years, ${ }^{5}$ and a similar argument could be made out in favour of Richard Elmes. But Elmes was still at the court when Frencham arrived in 1581, and most Russian medical historians having access to original records - William Richter, for instance - agree that Frencham was the real founder, and no fully-qualified, expert apothecary is mentioned in the Russian annals before his time, although other apothecaries worked at the Russian court. ${ }^{6}$ The Moscow Pharmacology and Pharmaceutics Museum supports this view.

It should be stressed that Russian medicine and pharmacy were virtually inseparable, both organizationally and therapeutically, throughout the one and a half centuries here under review. Consequently, emphasis will be placed as much upon pharmacy, in its broadest aspects, as upon the medical profession.

The Moscow Court Pharmacy served the exclusive needs of the Tsar and his family. For fear of poisoning, all medicines had to be thoroughly tested and tasted before being administered. Dr Jacob and James Frencham worked closely together, but it is clear that Ivan had specially commissioned Frencham to establish this, Russia's first chemist's shop; having once organized the pharmacy, Frencham left Russia in 1584, returning seventeen years later.'

The concept of the doctor-scholar-diplomatist-merchant is well exemplified by Robert Jacob. A distinguished doctor, the title of "Physician to the Household" was

trade with Russia via Archangel. (W. M. Richter, Geschichte der Medicin in Russland, Moscow, 1813, vol. 1, p. 291.) See also, T. S. Willan, The early history of the Russia Company 1553-1603, Manchester, 1956, p. 80.

"Hugh F. Graham, " "A brief account of the character and brutal rule of Vasil'evich, tyrant of Muscovy" (Albert Schlichting on Ivan Groznyi)', Can.-Am. Slav. Stud., 1976, 9: 206-207.

${ }^{\prime}$ See D. A. Wittop Koning's letter, Pharm. Hist., 1976, 6: no. I, back page; and I. Van Esso, 'De pharmaceutische Handelsbetrekkingen tusschen Nederland en Rusland in de 17e en 18e Eeuw', Pharm. Weekbl. Ned., 1938, 5: 9405.

' Richter, op. cit., note 3 above, p. 313.

' Paul Spehr, 'English chemists and Russian pharmacy', Pharm. J., 15 March 1898, 230-232. 


\section{Ivan the Terrible to Peter the Great}

first applied to him by Queen Elizabeth, whom he treated for gynaecological troubles. ${ }^{8}$ He may not have advanced medical science in Russia directly, but his versatility and usefulness to Ivan and, later, Theodore, in other roles unquestionably benefited Anglo-Russian relations and favoured British influence upon Russian medicine. Ivan had earlier suggested a military alliance with England, but Elizabeth wanted all the trade she could get, without the alliance. It was therefore in England's interest to cement cordial relations between the two countries, by whatever means. Dr Jacob, who had arrived in Russia with Frencham in 1581, was maintained by the Russia Company for several months until Ivan paid him a regular salary. He soon became on such good terms with the unpredictable Tsar, that in 1583 the latter asked him and Humphrey Cole, a visiting English priest, to write down the main points of religion in England. In the previous year, Ivan had followed up the doctor's proposal that he should marry Lady Hastings, the Queen's cousin, by dispatching a special embassy to arrange the match. But Ivan died in 1584, and Jacob returned to England. ${ }^{9}$ Two years later, he went back to Russia, specially commended by Queen Elizabeth to treat the wife of the new Tsar Theodore. His arrival at Moscow in the company of the English ambassador, Sir Jerome Horsey, bearing rich gifts for the Tsar, for Boris Godunov the Protector, and for his sister the Tsarina, resulted in very desirable privileges for the Russia Company. (Jacob later greatly offended the Company by trading in wax on his own account, at a considerable loss to the Company.) He also provided his close friend John Dee (who trained Richard Chancellor and others in navigational techniques) with information about Siberia and the north-east territories and was responsible for the extremely handsome invitation issued to Dee in 1586 from the Tsar and Boris Godunov to come to the Russian court, an offer which was declined.$^{10}$ Far from being the exception, the English doctor's multi-purpose role in Russia remained the accepted practice for many years to come.

When he became Tsar, Boris Godunov thought so highly of English doctors and apothecaries that, upon the recommendation of Sir Richard Lee, ambassador to Russia from July 1600 to April 1601 , he took into his service Lee's personal physician Dr Christopher Reitinger, born in Hungary but educated in England. Reitinger, as Godunov's senior physician, received his letters testimonial and seal (which still survive) for curing him of a dangerous illness. During Lee's mission, the Russians had requested James Frencham's reappointment at the Court Pharmacy, and Gregory Mikulin, a special envoy, was sent to London to re-engage him. Frencham arrived in Moscow in November 1602 with a letter to Godunov from Queen Elizabeth recommending him as "a man very skylfull in his profession," who, "for his honesty hath byn employed under us in a office of good reputation and trust." 11

\footnotetext{
DNB, vol. 29, p. 122; William Munk, The roll of the Royal College of Physicians of London, London, Royal College of Physicians, 1878, vol. 1, p. 88.

'Richard Hakluyt, The principal navigations voyages traffiques and discoveries of the English nation, London, Dent, 1927, vol. 2, p. 258.

${ }^{10}$ Information from Professor Alexander Zimin, USSR Academy of Sciences, in Richard Deacon, John Dee, London, F. Muller, 1968, p. 140; John H. Appleby, 'Dr Arthur Dee: merchant and litigant', Slav. E. Europ. Rev., 1979, 57: 33-34.

"John H. Appleby, 'Doctor Christopher Reitinger and a seal of Tsar Boris Godunov', Oxf. Slav. Pap., New Series, 1979, 12: 32-39.
} 


\section{J. H. Appleby}

Frencham is yet another example of the close links between pharmacy and commerce in the seventeenth century. London was then the only city where apothecaries were sufficiently numerous to form a separate guild; provincial apothecaries were often members of mercers' or grocers' guilds. ${ }^{12}$ In 1585 , the year after his return from Russia, Frencham, described as a merchant, was made a freeman, by birth, of Canterbury, becoming a member of the Common Council in 1591 and an alderman in 1592.13

Hence it was as much in the capacity of a merchant, as an apothecary that James Frencham returned to Moscow in 1602, travelling overland. He brought with him amulets and 167 medicaments with which to stock (or restock) the Court Pharmacy. His report on a severe outbreak of the plague, which he had encountered en route at Stettin, Danzig, Vilna, and Riga was filed in the Russian state archives and led to prompt measures by Godunov to prevent access from Poland and Lithuania. ${ }^{14}$ Frencham and Reitinger would have come into daily contact as Frencham placed the Court Pharmacy on a firmer basis. They may also have co-operated with John Woodall who, according to Keevil, accompanied Sir Thomas Smythe on his embassy to Russia (June 1604 to May 1605) several years before being appointed the first Surgeon General to the East India Company. Boris Godunov died on 13 April 1605, and it is likely that Reitinger would have returned to England with Smythe (and Woodall) in May. ${ }^{15}$

A turbulent period of Russian history followed Godunov's death. However, Michael's accession in 1613 inaugurating the House of Romanov, restored stability. The incorporation of the Society of Apothecaries of London in 1617, the publication of the Pharmacopoeia Londinensis in 1618, and Sir Dudley Diggs's trade mission of 1618 to Moscow (in which John Tradescant participated), all favoured the evolution of Russian medicine under British influence.

It is against this background that one must see the appointment of Arthur Dee as physician to the Emperor Michael in 1621. Son of the famous John Dee, Arthur had repeatedly clashed with the College of Physicians for illicit practice and selling apothecary medicines in London before becoming Queen Anne's doctor in 1615. ${ }^{16} \mathrm{His}$ arrival on the Russian scene coincided with the establishment in 1620 of the Apothecaries' Board, a formal office whose mandate was to control the work of the Kremlin Pharmacy and to regulate the importation of foreign medicines, on which Russia was heavily dependent. Depots were established for this purpose at the border towns of Polotsk and Mogilev and at the port of Archangel. Initially, the Apothecaries' Board was a small outfit directed by an apothecary-boyar - a nobleman

12 T. D. Whittet, 'The apothecary in provincial guilds', Med. Hist., 1964, 8: 245.

${ }^{13}$ Thomas Hawkes the younger, probably related to Dr Thomas Harvey, was bound as an apothecary's apprentice to Frencham for seven years in 1593. (Appleby, op. cit., note 11 above, p. 34.) Note that Frencham's father was Eustace, not Dustan: J. W. Cowper's error in transcription.

${ }^{14}$ Ibid.; Richter, op. cit., note 3 above, pp. 360-361, 448-455 (Frencham's medicines listed), and 396-401 (Commentary on the medicines).

15 J. J. Keevil, Medicine and the navy, London and Edinburgh, E. \& S. Livingstone, 1957, vol. 1, p. 225 Keevil does not give the source of his information; Appleby, op. cit., note 11 above, p. 36 - there is no mention of Woodall in the anonymous account of Smythe's embassy; John H. Appleby, 'New light on John Woodall, surgeon and adventurer', Med. Hist., 1981, 25: 251-268, see p. 253.

${ }^{16} \mathrm{John}$ H. Appleby, 'Arthur Dee and Johannes Bánfi Hunyades: further information on their alchemical and professional activities', Ambix, July 1977, 24: 98-99. 


\section{Ivan the Terrible to Peter the Great}

at the Russian court. During the whole of Tsar Michael's reign (1613-1645), there were only seven doctors, thirteen "lekars" (regimental surgeons), eight apothecaries, three "alchemists" (chemists), an oculist of sorts, a couple of translators, and a few clerical staff. ${ }^{17}$

As senior physician to Michael, Arthur Dee's duties covered not only the strictly medical field; he associated closely with English apothecaries such as Randolph Wardley, who came to Russia in 1624; examined new arrivals for their knowledge and professional competency; transacted official business for the Tsar in England during 1626-7, returning with mining experts; promoted the medical education at Cambridge University of a son of a German translator in Moscow; 18 and wrote treatises on alchemy in which the Tsar was interested. ${ }^{19}$ In these multifarious activities Arthur Dee, like other English physicians, exercised an influence well beyond the medical sphere. He was in addition a polyglot, widely travelled, whose experience, cosmopolitan outlook, and adaptability rendered him indispensable in fostering the early all-round growth and development of the Apothecaries' Board. Moreover, not the least of his considerable energies was harnessed to procuring drugs for the use of the Russian court. In order to appreciate Dee's important function as an importer of medicines, a short review of the position in England is relevant.

A surviving draft bill of proceedings by the Royal College of Physicians in the Star Chamber against various members of the Society of Apothecaries during 1634 and 1635, reveals that the Apothecaries supplied Russian, Polish, Turkish, and other foreign customers with medicines in the $1630 \mathrm{~s}^{20}$ The foreigners, however, often preferred formulae different from those officially prescribed by the Pharmacopoeia Londinensis, from which many good medicines were excluded - lac sulphuris (precipitated sulphur), for instance, often prescribed by Sir Theodore Mayerne, royal physician, Fellow of the College of Physicians and a friend and correspondent of Arthur Dee. ${ }^{21}$ Much of this legal case revolved around the lac sulphuris supplied by Edward Cooke and George Haughton. As far as trade with Russia is concerned, the most interesting testimony came from the apothecary Richard Litlar about Edward Cooke, a wealthy man who practised medicine as a sideline while carrying on the normal business of an apothecary. Litlar declared that "Cook hath for 7. or 8. yeares serued the Emperor of Muscovia \& diuers of his Peeres \& Nobility with all kinds of phisick prescribed by phisicians \& made according to the Pharmac[opeia]". Arthur Dee himself, described as having been the Emperor's principal physician for fourteen years, and who had left Russia in 1634 for the post of Physician Extraordinary to

${ }^{11}$ M. K. Kuzmin, Istoriya meditsiny: ocherki, Moscow, Nauka, 1978, pp. 34-5; N. Novombergsky, Cherty vrachebnoy praktiki v Moskovskoy Rusi, St Petersburg, 1904, pp. 40-41, copy in the Wellcome Library.

18 Appleby, op. cit., note 10 above, pp. 40-42.

${ }^{19}$ Appleby, op. cit., note 16 above, pp. 100-105; John H. Appleby, 'Some of Arthur Dee's associations before visiting Russia clarified, including two letters from Sir Theodore Mayerne', Ambix, March 1979, 26 : 5-9.

${ }^{20}$ (a) Guildhall Library, MS. 8286, draft bill, 1634-5; (b) A history of the Worshipful Society of Apothecaries of London, abstracted and arranged from MS. notes of Cecil Wall by $\mathrm{H}$. Charles Cameron, rev. and ed. by E. Ashworth Underwood, Oxford University Press, 1967, vol. 1, p. 48, and a detailed summary of the proceedings by Underwood, p. $221 \mathrm{ff}$.

${ }^{21}$ Appleby, op. cit., note 19 above. 


\section{J. H. Appleby}

Charles I, also testified to the same effect on behalf of Cooke. ${ }^{22}$

It had long been the practice in Russia for incoming apothecaries and doctors to bring medicines, books, and even surgical instruments with them. When, therefore, $\mathrm{Dr}$ Timothy Willis had replaced Dr Mark Ridley in 1599, one reason why he was dismissed within three weeks of his arrival at Moscow was that he could not display any books or drugs, having journeyed overland and sent his medicines by sea. Nevertheless, he was given what purports to be the first medical examination in Russia - by the chancellor Shchekalov. Later, he wrote works on alchemy and quite possibly it was his lac sulphuris which, as one witness testified at the above proceedings, resulted in the apothecary Harrison being fined at the Hall "for making lac: sulph: according to a receipt of Doctor Willis, \& for selling it to Cook who compleyned of the ill condicion \& badnes thereof." ${ }^{23}$

From Litlar's and Dee's testimony it is quite clear that Edward Cooke, and possibly others, under the auspices of the Society of Apothecaries, had been supplying the Russian court with a wide range of medicines since 1627, when Dee returned from England, having presumably arranged the initial consignment for the Apothecaries' Board. That he should have done so comes as no surprise when one realizes that not only was he a member of the Russia Company (as were two of his sons-in-law - his large house became the Company's Moscow headquarters in 1636) and a mercer, but he was also an energetic and enterprising merchant in his own right, as surviving documents attest. ${ }^{24}$

The records of the Apothecaries' Board, which date only from 1630 and are incomplete, provide firm evidence of how heavily dependent the Russian court was on English medicines at this time. Thus, in June 1630, Arthur Dee petitioned for apothecary supplies to be transported from Archangel to Moscow, having arranged for them to be brought over from England by a son-in-law. More explicitly, in his petition the following year, Dee stressed that every year he had sent his servants to the port of Archangel to fetch all kinds of medicines and court requirements dispatched to him from England. Approval was also given to his petition for transport in June 1632, when William Smith, an English merchant, expressly shipped apothecary medicines from England for the Tsar. ${ }^{25}$ Neither the records of the Apothecaries' Board nor those of the Society of Apothecaries of London give any further details, so that it is difficult to evaluate the role performed by the latter during Michael's reign or the full extent of the apothecary medicines and wares. Certainly, the initiative largely rested in the hands of men like Edward Cooke and Arthur Dee, and there is no doubt that Dee's influence on shaping the Apothecaries' Board was far more extensive than that of physicians of other nationalities. The English apothecaries William Tewe and his son Robert were also active in Moscow. 26

Eleven years after Arthur Dee's departure from Russia, Tsar Michael died and Alexis came to the throne. The thirty-one years of his reign, from 1645 to 1676, were

${ }^{22}$ Op. cit., note 20 above: (a) f. 42; (b) p. 296.

${ }^{23}$ Ibid., p. 291; Appleby, op. cit., note 16 above, p. 99.

${ }^{24}$ Appleby, op. cit., note 10 above, pp. 32, 37-40, 44-46.

$2 s$ Ibid., pp. 47-48.

${ }^{26}$ Ibid., p. 48. 


\section{Ivan the Terrible to Peter the Great}

marked by developments in the organization of the Apothecaries' Board, culminating in the founding, in 1672, of the "New" or "Lower" Pharmacy, as it was called to distinguish it from the "Old" or "Upper" Court Pharmacy in the Kremlin.

Prompted, no doubt, by the constant spate of wars and the need to make medical provisions for the forces, in 1654, the Apothecaries' Board organized medical supplies and the dispatch of the first sizeable contingent of "lekars", or regimental surgeons, to Smolensk, which Alexis had wrested back from Poland. That same year, the Board founded the first Russian medical school. Thirty youths were selected and given instruction in surgery, anatomy, botany, pharmacology, practical diagnosis of internal diseases, and ambulatory medicine; thirteen of them first graduated in 1658. Apart from the syllabus, not much is known about this early medical school which, in any case, did not last long. ${ }^{27}$ Foreign doctors attached to the court are thought to have provided much of the instruction. ${ }^{28}$

On the economic front, rivalry between the Russia Company and the Dutch flared into conflict. In June 1649, the Tsar, outraged by the execution of Charles I, issued an edict effectively banishing English merchants from the interior of Russia and leaving them only the port of Archangel. Under the Protectorate (1653-9) various missions were sent in attempts to re-establish relations, with no success until the Restoration (1660). ${ }^{29}$ Disputes over whale and other fishing rights, cloth markets, and the Muscovy trade resulted in the two Anglo-Dutch wars of 1652-4 and 1664-7. In 1667 a new statute was passed prohibiting all foreigners from custom-free trading in Archangel, and by 1669 , the Dutch had ousted the English from their pre-eminent mercantile position in Russia. ${ }^{30}$

Despite the Russia Company's waning influence, and the fact that the Netherlands also exported medicines, Russian medical sources attest that from 1660 to 1670 the bulk of medicines continued to come from England. An English merchant was commissioned in 1660, and again in 1670, to buy apothecary medicines consisting of Jesuit's bark, sassafras, and lignum cassiae. In 1661, John, later Sir John, Hebdon, agent for the Tsar and the Russia Company, procured large pharmaceutical supplies for the Russians; two years later, he consigned six trunks and two barrels of apothecary goods from England. ${ }^{31}$

In 1659, Samuel Collins took up the post of physician to Tsar Alexis. A native of Braintree in Essex, he had studied medicine at Leyden and Padua and acquired wide experience and erudition. At this time, there were three principal apothecary gardens at Moscow, including the "Tsar's Garden" in the Kremlin, where rare medicinal plants grew in an exotic setting. The intimate links between medicine and botany are

${ }^{27}$ B. N. Palkin, Russklye gospitalnyye shkoly XVIII veka i ikh vospitanniki, Moscow, Medgiz, 1959, pp. $130,4$.

${ }^{28}$ A. Lebedenskaya, 'Pervaya voyenno-meditsinskaya shkola na Rusi', Voyenno-istorichesky zhurnal, March 1941, 3: 98.

${ }^{29}$ Inna Lubimenko, 'Anglo-Russian relations during the first English revolution', Trans. R. Hist. Soc., 4th Series, 1928, 11: 39-58.

${ }^{30}$ Inna Lubimenko, 'The struggle of the Dutch with the English for the Russian market in the seventeenth century', ibid., 1924, 7: 27-51.

${ }^{31}$ N. Novombergsky, Materialy po istorii meditsiny v Rossii, St Petersburg, 1905, vol. 1, supplement pp. 14, 48-49, 52-53. Copy in Wellcome Library. 


\section{J. H. Appleby}

well illustrated by two comprehensive tracts which Collins wrote in 1665 , one on obesity (for the benefit of the corpulent monarch), the other on the medical uses of the valerian and burdock plants. Both treatises were written in the form of lengthy letters in Latin; they demonstrate his considerable learning and thorough knowledge of medicine and medicinal plants (of which at least sixteen are mentioned). Although by the middle of the seventeenth century all foreign doctors and apothecaries in Russia were required to keep written records of the treatment they prescribed, Collins's tracts were singled out as exceptional, recorded in their entirety, and carefully preserved, along with his prescriptions, for the edification of other medical men at the Apothecaries' Board. ${ }^{32}$

Like Arthur Dee before him, Collins also transacted a variety of business - commercial, technical, political, and diplomatic - for the Russians as well as the English. In April 1662, he received official permission to return to England on leave, sailing with the two Russian ambassadors sent to re-establish friendly relations with England after the Restoration. He used the opportunity to purchase medicines and books for the Tsar from London and the Continent.

He also introduced elements of English culture to the Tsar by translating the copies of the London Gazette sent regularly to him by friends. ${ }^{33} \mathrm{His}$ offer to correspond from Russia with the Royal Society led to a meeting with Robert Boyle and a series of letters that lasted for several years. This equipped Boyle with a mass of indispensable information about the effects of cold and freezing and about Russian natural history. Nearly all the material was the fruit of Collins's own observations and experiments; much of it is incorporated, with acknowledgements, in Boyle's scientific writings. Even more information on Russia in general was extracted from his letters to Boyle and, after Collins's early death, published under the title The present state of Russia (1671). ${ }^{34}$

The second edition (1683) of Boyle's work, New observations and experiments touching cold, indicates that, in return for this information, he had furnished Collins with some "pleasing and yet effectual Chymical Medicines, that were very well lik'd, and nobly rewarded, by the Czar." 35 This is also suggested by Collins himself, in one of his few surviving letters to Boyle. "Sir", he requested, "if I stay here, pray assist me with some rarities in our art. I shall be remote enough to do no man injury by them. What I shall find worthy of a person of your learning and experience, I shall contribute as an humble acknowledgement of your civilities." ${ }^{36}$ In the same letter, written on his return to Russia in 1663 in the company of Andrew Marvell, the poet and

\footnotetext{
${ }^{32}$ N. Novombergsky, Vrachebnoye stroyeniye v do-petrovskoy Rusi, Tomsk, 1907, pp. 99-100, 217-218; Novombergsky, op. cit., note 31 above, supplement nos. 154 and 1058 (translated texts of the originals) and pp. 1-8 (prescriptions).

${ }^{33}$ Public Record Office, Francis Sanderson to Joseph Williamson, 6 February 1666/7, State Paper 88/11-40r-v. Cited in Geraldine Phipps, 'Britons in seventeenth-century Russia', PhD thesis, University of Pennsylvania, 1972, p. 346.

${ }^{34}$ Leo Loewenson, 'The works of Robert Boyle and The present state of Russia by Samuel Collins (1671)', Slav. E. Europ. Rev., 1955, 33: 470-485; J. H. Appleby, 'British doctors in Russia, 1657-1807: their contribution to Anglo-Russian medical and natural history', unpublished thesis, University of East Anglia, June 1979, pp. 13, 17-20.

${ }^{35}$ Robert Boyle, The works of the Honourable Robert Boyle, London, 1772, pp. 463-464.

${ }^{36}$ Collins to Boyle, Vologda, 20 November 1663, in ibid., vol. 5, p. 642.
} 


\section{Ivan the Terrible to Peter the Great}

dramatist, who was acting as secretary to England's envoy, the Earl of Carlisle, Collins discussed several typically Russian diseases and the medicines he used for them. Among the matters on which he solicited Boyle's advice was "the fixing of arsenic a ready cheap way. One Smart, that dwells in Dorchester house, a drudging operator, made me pay ten-pence for an ounce, but it was well fixed, and may be given inwardly." He adds: "That operator Smart . . sold me a stinking balsam, that I have used with miraculous success in sore eyes. I forget what he calls it; Mr Buttersby can help you to it. He makes sulphur martis, pray impart it." And he asked Boyle to write to "Mr Buttersby at the great Helmet in Fenchurch-street, who does provide our medicaments for us and is a very honest man and able apothecary." John Battersby, who supplied Russia with medicines, had served his apprenticeship under Richard Holland and Edward Cooke. A friend of Samuel Pepys, he was Master of the Apothecaries (1674-5) and his pestle and mortar are still on display at the Society. Peter Smart had been appointed in 1624 to the same George Haughton who, together with Edward Cooke, had played a leading part in the proceedings brought against the Apothecaries by the College of Physicians in 1644. Boyle mentions him in his Philosophical diary for 1655 as a person from whom he received information about chemical processes and medicinal preparations.

Since the apothecary Robert Benyon, who brought medicines to Russia, was, with Battersby, also apprenticed to Richard Holland, it is reasonable to assume that Holland, as well as Edward Cooke and possibly George Haughton, were all involved at one time or another in providing apothecary medicines for the Russians and that Smart, Benyon, and Battersby carried on this line of business. The Apothecaries' records - except for the 1644 proceedings already described - shed no light on these activities, but all other evidence points to a well-organized exporting concern, initiated probably by Arthur Dee and continued by contacts with other English apothecaries and doctors at the Russian court, such as Samuel Collins. Clearly, the individuals named above who produced medicines for Russia operated within the orbit of the Society of Apothecaries. Possibly, they exported, with immunity, drugs not included in the Pharmacopoeia Londinensis, which would have been difficult to market in London because of the restrictions imposed by the College of Physicians.

Besides Collins, it was the apothecary Robert Benyon who made the biggest impact upon the Russian medico-apothecary system during Alexis's reign, by supplying the Apothecaries' Board with pharmaceuticals and by building up its library. In 1656, the apothecary Robert Tewe had petitioned to return to England. One of the most prominent and highly regarded apothecaries at the court, whom the Russians later tried in vain to re-recruit, Tewe recommended Benyon as his replacement. ${ }^{37}$ The latter arrived at Archangel on 9 August 1656, bringing eight books with him. These books constituted the foundation of the library of the Apothecaries' Board, although a library of sorts had existed much earlier: we know, for instance, that Richard Barnes, an English trader in Moscow, was allowed to borrow a manuscript in the spring of $1605 .^{38}$ Benyon's books are located today in the USSR Academy of Sciences Library at Leningrad, and at the front of each an entry in Russian reads: "Book of the

${ }^{37}$ Spehr, op. cit., note 7 above, part 2, 26 March 1898, pp. 305-307.

${ }^{38}$ S. P. Luppov, Kniga v Rossii v XVIII veke, Leningrad, Nauka, 1970, pp. 203-207. 


\section{J. H. Appleby}

Apothecaries' Board brought by Romanov Biniyan". The Library also has the original list of the eight titles, followed by a ninth work - a commentary by Hermann Grube on recognizing plants for medical purposes. Published at Frankfurt, it is dated 1669, which means that Benyon purchased it three years after his arrival in Moscow. Six of the books, also from Frankfurt, are: the Pharmacopoeia Galeno-chemico cattolica of 1651; four titles by Andreas Libavius (1613-15) on arcane chemistry and Rosicrucianism; and the 1655 edition of Museum Wormianum, the famous work by Ole Worm, the Danish physician and antiquarian. ${ }^{39}$

Benyon worked closely with Collins, and between them they appear to have stocked the Apothecaries' Board with drugs. Paul Spehr, an informed writer on the history of English and Russian pharmacy, emphasizes that Benyon's skill as a professional apothecary is proved by "an extensive record that has been preserved of the laboratory of the Court drug-store, according to which it was his duty to provide for the most complicated and difficult preparations." Unfortunately Spehr, who had access to original Russian records, did not indicate the source of his information. ${ }^{40}$

Robert Benyon, who married in Russia, returned briefly to England, for in 1666 we find him refusing to accept the livery of the Apothecaries' Company. ${ }^{41}$ We know from the date in the book by Grube that he was back in Moscow by 1669 . He was commissioned by the Russians in 1670 to buy all kinds of apothecary goods in England and other countries. The following year, he purchased a very large consignment of pharmaceutical wares and medicines in Amsterdam, while in 1672 he brought over from England two whole trunks of gilded medicine bottles. ${ }^{42}$ An Apothecaries' list marks him as "Gone" in $1673,{ }^{43}$ and, according to Spehr, a Russian document dating from 1676 confirms that he had been appointed to a position at the New Court Pharmacy.44 At any rate, it is evident that Robert Benyon, operating on a large scale within the general framework of the Society of Apothecaries of London and the Apothecaries' Board at Moscow, played a significant part in the expansion of Russian pharmacy.

The "New" or "Lower" Pharmacy, which Benyon helped to establish and where he worked for a few years, was opened in 1672 in a warehouse used for storing medicines. It was primarily designed to cater for the needs of court officials and the army, but some private individuals were allowed medicines against payment. Unlike the "Old" or "Upper" Pharmacy in the Kremlin, it was placed on a financial footing. The cashier allocated money received towards daily business such as buying medicines and carrying out repairs, handing over what remained to the Apothecaries' Board directed by a boyar. The first apothecaries' tax was introduced in 1672, and the next year the Tsar granted both pharmacies a monopoly of purchasing medicines, mostly of plant origin. The new pharmacy was allowed to sell spirits, alcoholic tinctures, and various

\footnotetext{
${ }^{39}$ M. S. Filippov (editor), Istoriya Biblioteki Akademii Nauk SSSR 1714-1964, Moscow/Leningrad, Nauka, 1965, pp. 150-151, 428.

${ }^{40}$ Spehr, op. cit., note 37 above.

${ }^{41}$ Letter from Dr T. D. Whittet, past Chairman of the Faculty of the History of Medicine and Pharmacy and present Master of the Society of Apothecaries of London.

${ }^{2}$ V. I. Lipsky, Istorichesky ocherk Imperatorskago S.-Peterburtskago Botanicheskago Sada, St Petersburg, 1913, pp. 139-141.

${ }^{43}$ Whittet, op. cit., note 41 above.

44 Spehr, op. cit., note 37 above.
} 


\section{Ivan the Terrible to Peter the Great}

medicaments. It marked a real development in Russian pharmacy.4

Peter the Great, who ascended the throne in 1689 , had a strong interest in medicine. During his "Grand Embassy" to Holland and England (1697-8), he visited hospitals, anatomical theatres, and apothecary gardens recruiting, through his agents, a veritable army of medical personnel. In his first sixteen years as Tsar, no fewer than seventeen doctors, eighty-seven surgeons, one ophthalmologist, and nine apothecaries from abroad arrived in Russia. During his reign, the entire Russian medical system was radically reformed to meet the needs of the times. Peter's tremendous drive and enthusiasm provided the initial impetus for these changes, but their practical implementation was to a large extent in the hands of one Scottish doctor, Robert Erskine, whose organizational and executive ability was outstanding. Indeed, Russian medicine, botany, and natural history in general owe more to his pioneering genius than to any other person of the period. ${ }^{46}$

Robert Erskine, the sixth surviving son of Sir Charles Erskine of Alva, was born in 1677. At the age of fifteen, he was apprenticed for five years to an Edinburgh surgeonapothecary; he then studied anatomy, surgery, chemistry, and botany for two years in Paris, partly under the supervision of the distinguished surgeon and teacher Du Verney, professor of anatomy at the Jardin Royal des Plantes Médicinales. Erskine next went to Holland where he graduated MD at Utrecht University in 1700. On his return to England, he developed into a distinguished anatomy lecturer at a London hospital school or college; his skill in dissecting the human body and his anatomical observations of vipers received public testimony in related works by Joseph Morland and Richard Mead. This publicity secured his election to the Royal Society in November 1703 - on the same day as Mead.47

On 30 May 1704, Erskine was made a freeman of the Russia Company, ${ }^{48}$ departing immediately afterwards for Moscow, where he became house doctor to Prince Menshikov, the Tsar's principal aide - a position, however, which he held only for a short time, as Peter made him his own chief physician within a few months.

In November 1705, shortly before Erskine's arrival in Russia Peter the Great issued an important ukase, allowing the establishment of the first eight private pharmacies, at their own cost, in the capital's central conurbations. They held a free licence, which entitled them to serve the general public and protected them from competition by unreliable practitioners. They came under the control, not of the Apothecaries' Board, but of the Foreign Office, the Tsar, quite rightly, counting only on foreigners to apply for the licence. The first private pharmacy at St Petersburg, on the other hand, did not open until 1760 because of the new capital's small, slow-growing population and the dominance of the state pharmacy system. ${ }^{49}$

The year 1706 was a turning-point in Erskine's career; Peter appointed him

${ }^{45}$ H. E. Müller-Dietz, Aerzte im Russland des achtzehnten Jahrhunderts, Esslingen, 1973, p. 30.

${ }^{46}$ John H. Appleby, 'Robert Erskine - Scottish pioneer of Russian natural history', Archs nat. Hist., 1982, 10: 377-398.

${ }^{47}$ Appleby, op. cit., note 34 above, pp. 38-43.

4 Guildhall MS. 11741/3, f. 137, The Russia Company's Court Minutes Book.

49 Paul Spehr, 'Early English pharmacists in Russia', Chem. Drugg., 24 June 1922, p. 195; Appleby, op. cit., note 46 above, pp. 31-32. 


\section{J. H. Appleby}

"archiater", or director of the Apothecaries' Board with supreme responsibility for all Russia's medical services. Thus, at one stroke, the Tsar deprived the apothecaryboyars of the loftiest position in the medical hierarchy and the Apothecaries' Board became a state institution. In addition, as chief physician to the Tsar, Erskine accompanied him on his military campaigns and his frequent journeys abroad. His diaries and reports of some of the monarch's illnesses and the treatment he prescribed for them have been preserved..$^{30}$

Under Erskine's archiatership a new central pharmacy was constructed in a building intended for a mint, to the east of the Kremlin. Reconversion started in 1706, and was completed three years later. Meanwhile, in 1707, the Apothecaries' Board was renamed Apothecaries' Chancery or, to give it its full title, "Chancery of the Chief Court Pharmacy". The traveller Cornelius Le Bruyn met Robert Erskine at this stage. His vivid picture of this "Dispensatory for medicines", as he calls it in his book of travels, deserves quoting in full for the comprehensive details that it conveys of this showpiece of Europe:

It is a very fine and lofty building, with a beautiful tower in the front. Its situation is to the east of the castle, and on the spot where formerly was a market for fowls. The passage to it lies through a large base court, at the end of which is a great staircase, that conducts to the first apartment, which is vaulted, and very lofty, and twenty feet in breadth. People were employed in painting it in distemper at that time. The side walls are embellished with fine cross work, and others are to be decorated with China syrup-pots, and other vases, on the top of which the arms of his Czarian majesty are enamelled. There are two doors to this apartment, one of which affords a passage into the magazine of medicinal herbs; the other opens into the chancery, or office of accounts belonging to the house. There are also very beautiful halls finely vaulted, particularly two, which entirely correspond in structure, one of which serves for a laboratory, and the other for a library, wherein extraordinary plants and animals are likewise preserved. Beside these apartments, there are several others, particularly that of the president or doctor; and another which belongs to the apothecary or his domestics. The doctor has also the direction of the chancery, and has under him a vice-chancellor, and several commissioners, and he has even power to punish with death those who are under his direction, whenever they merit such a treatment. All the physicians, chirurgeons, and druggists, receive their salaries in this office of chancery. Eight apothecaries are employed in this dispensatory, and they have under them five boys, and above forty workmen; and from hence his majesty's troops and navies are supplied with all the drugs and medicines they want. ${ }^{31}$

Le Bruyn adds that the Tsar, who held Robert Erskine in great esteem for his capacity and personal merits,

made him a present of two thousand crowns when he engaged in this great and arduous work. He seemed to be persuaded, when I left Moscow, that every thing would be compleated in the space of a year; and he was then employed in collecting from all quarters, and disposing with the utmost elegancy on paper, all the principal herbs and flowers, which are useful in medicine, and of which he had already filled a book. He likewise shewed me that he intended to send into Siberia for a collection of simples, flowers and plants. This dispensary has two gardens.

Erskine's own herbal of plants that he gathered around Moscow in 1709, is the oldest surviving Russian herbal. It is kept in very good condition at the Russian Academy's

so In the authoritative Russky Biografichesky Slovar (St Petersburg, 1900, vol. 2, pp. 280-281; reprinted New York, 1962), L. Weinberg pays tribute to Erskine's prodigious energy as director of the Apothecaries' Board, which resulted in Russian medicine being radically transformed: "One is fully justified in calling Erskine's activity in Russia the first period of changes and improvements in the history of Russian medicine." Bearing in mind that all forms of medicine, botany, pharmacy, and natural history came under the aegis of the Board, this assessment is in no way exaggerated.

${ }^{31}$ Cornelius Le Bruyn, Travels into Muscovy, Persia and parts of the East-Indies, London, 1737, vol. 1, p. 179. 


\section{Ivan the Terrible to Peter the Great}

Komarov Botanical Institute in Leningrad. Erskine considerably extended the collecting and systematization of herbs and items of natural history in Russia. In the spring of 1702, Peter had issued a decree ordering Siberian medicinal plants and substances to be sent to the Apothecaries' Board.

A dramatic event, which altered all aspects of Russian life, was the founding of St Petersburg in 1703. Built by Peter the Great on a marsh as an outpost against the Swedes, the city is sited at the head of the Gulf of Finland, on both banks of the River Neva and the islands forming its delta. It was the capital from 1712 until 1918, and by its foundation Peter, in the poet Pushkin's phrase, aimed at "cutting a window through on Europe", that is, modernizing the country by opening it up to Western influence.

Robert Erskine also played a very active role in the founding of St Petersburg. Soon after the first St Petersburg Garrison Pharmacy had been established in 1704, he ordered the apothecary in charge of it to draw up an inventory. Later known as the Chief or Upper St Petersburg Pharmacy, it was located originally in the Cronstadt fortress and then, because of dampness, moved into the actual building of the Apothecaries' Chancery, whose transfer to the new Russian capital, no mean undertaking in itself, had been planned and organized by Erskine. Unlike the hospital pharmacies and the court pharmacy, it sold medicines at prescribed prices and supplied, amongst other materials, the artillery with special requirements such as corrosive sublimate. It was followed by the Lower St Petersburg Pharmacy and the Admiralty Pharmacy (on Admiralty Island). Moscow Garrison Pharmacy, the second of its kind in Russia, also opened in $1704 . .^{52}$ Erskine carried overall responsibility for the inception and running of all these pharmacies. However, he had little direct connexion with the hospitals, as they came under the Russian Church's Synod. The "Hofshpital", or Moscow Military Hospital, was patterned on the Greenwich Hospital which Peter had visited. Founded in 1706, it contained Russia's second medical school, being principally a hospital for training doctors and surgeons. The St Petersburg Naval and Military Hospital was built in $1717 .{ }^{53}$

During the first two decades of the eighteenth century, Russia continued to be embroiled in a struggle with Sweden for supremacy of the Baltic countries and to be involved in a complex system of European alliances. The records of the Apothecaries' Chancery from 20 March 1706 to 14 March 1710 provide a detailed account of the administrative side of Erskine's supervision of soldiers' medical examination and treatment by doctors, as well as the medicines destined for the navy. Erskine accompanied the Russian army, whether commanded by the Tsar or Prince Menshikov, on many of its campaigns, ${ }^{54}$ and it is to his credit that he organized Russian medicine on a war footing.

He also successfully fulfilled the delicate role of a mediator in Anglo-Russian political affairs on numerous occasions and exercised considerable influence over the Tsar in this, as in many other respects. Peter the Great, not the easiest person to get on

\footnotetext{
32 Yakov Chistovich, Istoriya pervykh meditsinskikh shkol v Rossii, St Petersburg, 1883, pp. 570-571.

${ }^{33}$ Novombergsky, op. cit., note 31 above, vol. 4 (Tomsk, 1907), pp. 410-415, 420-426, 432-433, 435-436, 603-605.

${ }^{34}$ Appleby, op. cit., note 34 above, pp. 48-49, 64-65.
} 


\section{J. H. Appleby}

with, made Erskine a privy councillor in 1716 for his "many and most faithful services" - a mark of high distinction."ss Although Erskine wrote towards the end of this year in a letter to Charles Whitworth, British envoy to Russia, that he would rather "write twenty receipts than one [political] letter", he interceded for his fellowcountrymen with the Tsar and was often consulted by him on the vexed questions of European politics and diplomacy. A letter that Erskine wrote to Sir John Norris, Admiral of the British Baltic Fleet, states that he had communicated the contents of Norris's letter to the Tsar, who wished it to be understood that he was willing to cooperate in an alliance with Britain against Sweden, subject to certain provisions, and even offering him the post of Admiral of the Russian Fleet. ${ }^{56}$

As a freeman of the Russia Company, Erskine traded on his own account, invested in the East India Company, and sent Russian hides to be sold in Leghorn/Livorno. Among letters to Erskine from over 200 correspondents, surviving intact in the USSR Academy of Sciences Archives today, are requests from two separate London merchants in November 1709 for Erskine to use his influence to promote a project for importing tobacco and another enterprise in Russia. ${ }^{57}$ Other roles performed by Erskine included engineering Peter's membership of the French Academy of Sciences and acting as scientific consultant on Russia to Leibnitz.

Moscow Apothecaries' Garden, established in 1706 and reorganized two centuries later into Moscow University's Botanical Garden, came under Erskine's jurisdiction, and he probably took some (unspecified) part in its running. However, there is clear evidence that he was the organizer and superintendent of the St Petersburg Apothecaries' Garden, which was laid out on Apothecaries' Island in 1714. It was Russia's first specifically medicinal garden, becoming subsequently the Komarov Botanical Institute of the Russian Academy of Sciences. Two specialists, invariably foreigners, acted as overseers - a "provizor", or fully-qualified dispenser who designated the herbs to be grown and the parts to be used in medicine, and a gardener who cultivated them. Medicines were prepared from fresh and dry herbs and special doctors were delegated by the Apothecaries' Chancery to supervise this activity, like the "botanical physicians" or "court herbalists" appointed by the Stuarts. ${ }^{88}$ Robert Erskine, through his own training, interests, and organizational talent, greatly enlarged the sphere of medical botany in Russia.

By the close of the seventeenth century, the Russians were importing most of their medicines from Holland (Amsterdam), Germany (the Hanseatic ports of Hamburg and lubeck), and England. Although the English no longer monopolized the trade, they still retained a large share of the market. This is confirmed by Peter Postnikov, Russia's first doctor of medicine. During Peter the Great's visit to England in 1698, Postnikov and Dr Termond, a German doctor in the Tsar's service, helped to recruit

\footnotetext{
ss Chistovich, op. cit., note 52 above, p. XXLXVI (supplement XI).

${ }^{56}$ British Library, Stowe MS. 230, f. 122, French translation of Erskine's letter of May 1717 to Admiral Sir John Norris.

${ }^{37}$ Leningrad, USSR Academy of Sciences, Archives, Fond 120/1, no. 100, f. 1 and no. 101, ff. 8-9v. This virtually untapped correspondence, acquired on Erskine's death by Peter the Great, is a valuable source of information about all aspects of Erskine's direction of the Apothecaries' Chancery.

ss Lipsky, op. cit., note 42 above, pp. 16-18, 381-382.
} 
medical personnel, purchase medicaments, instruments and books, and to inspect English medical institutions. On 19 April that year, Postnikov had a "discourse" in London with Dr Bernard Connor, physician to the Polish king, Jan III Sobieski, and author of The history of Poland (1698). Postnikov told Connor that "Physick was an Honourable and Beneficial Profession" in Russia, that "they make no Doctors of Physick in Muscovy" (Postnikov was an MD of Padua), that the Russians "use our [i.e. English] Druggs brought to Archangel, and by the Baltic Sea", and that the "Customs of Archangel bring him [the Tsar] every year a million of Gold Ducats". 39

Under Erskine's tenure of office as archiater, England continued to send medicines, but the majority of supplies appear to have come from Holland. The famous Dutch apothecary, Albert Seba, for instance, wrote to Erskine at the end of 1711, sending him a sample of his medicines and pointing out that a contact had informed him of Erskine's special predilection for exotics, knowing that he, Seba, with his world-wide contacts at Amsterdam, had a good stock of "officinal drugs". For several years, he continued, he had been supplying the Russian Admiralty (also under Erskine's jurisdiction) with medicines, and since he understood that Erskine directed the procurement of medical provisions both for the court and for the field apothecaries, he hoped to meet these demands as well. In 1716, Seba also approached Erskine about the medicines (1,500 guilders' worth) that he was shipping to Archangel for the Apothecaries' Chancery at St Petersburg. ${ }^{60}$

It is impossible to overestimate Erskine's resourcefulness and enterprise in obtaining medicines for the Apothecaries' Chancery, which had to supply them to the armed forces and all large Russian towns on an annual budget of 5,000 roubles. During his journeys abroad with the Tsar, he frequently used the opportunities to buy medical items for the Chancery. For example, while they were at Copenhagen in 1716, he arranged for a whole shipload of apothecary supplies, forty barrels of strong spirits, and all kinds of rarities to be sent to St Petersburg. ${ }^{61} \mathrm{~A}$ year later, he purchased wax anatomical models and surgical exhibits at the Jardin Royal in Paris. ${ }^{62}$

Between 1711 and 1712, the library and collections housed in the Apothecaries' Chancery were transferred from Moscow to St Petersburg. Then, in 1714, the Kunstkammer, or Chamber of Curiosities, Russia's first cultural and natural history museum, was founded in the new capital, with Erskine as its director and chief librarian. Erskine performed a vital role in negotiating the purchases of world-famous collections for the Kunstkammer, including the Dutch surgeon Frederick Ruysch's outstanding anatomical preparations and natural history cabinet and Albert Seba's cabinet of curiosities. ${ }^{63}$ The Kunstkammer became the Academy of Sciences' Museum, and Erskine's own large collection of curiosities, medals, surgical instruments, and anatomical specimens made an important contribution to it. In addition, he obtained Dr Archibald Pitcairne's and other outstanding libraries of the time, which, together with his own excellent one, formed the cornerstone of the future

\footnotetext{
${ }^{39}$ R. H. Dalitz and G. C. Stone, 'Doctor Bernard Connor ... , Oxf. Slav. Pap., New Series, 1981, 14: 33-35.

${ }^{60}$ Appleby, op. cit., note 46 above, p. 384

${ }^{61}$ Materialy dlya Istorii Imperatorskoy Akademii Nauk, St Petersburg, 1885, vol. 1, p. 1.

${ }^{62}$ Chistovich, op. cit., note 52 above, p. 384.

${ }^{63}$ Appleby, op. cit., note 46 above, p. 384-390.
} 


\section{J. H. Appleby}

Academy's Library.64

As president of the Apothecaries' Chancery, Erskine planned the details of Russia's first scientific expedition, to Siberia, led by Daniel Messerschmidt, the German doctor and naturalist whom he had recruited into the medical service. He also supervised all medical missions, including those of two of his compatriots: Thomas Garvine, a surgeon who went to China in 1715 and may have introduced knowledge of Chinese variolation techniques to Russia on his return in 1718; ${ }^{65}$ and Dr John Bell, ${ }^{66}$ who has left a very readable and informative account of his journeys to Persia and China, in Travels from St Petersburg in Russia to diverse parts of Asia (1763).

Finally, both the Tsar and Robert Erskine were very interested in balneology Erskine discovered a spring containing iron on the outskirts of St Petersburg. They, and two German doctors, laid the foundations of this form of treatment, which thrives today.

Robert Erskine died on 30 November 1718, only forty-one years old. He was given a splendid funeral and buried with high honours at the Alexander Nevsky Monastery in St Petersburg. He rendered an incalculable service to Russian medicine in the broadest sense as an innovator, reorganizer, and developer, transforming and modernizing the whole medical apparatus. Although other British doctors in Russia - such as James Mounsey, the last archiater of the renamed Medical Chancery in $1762^{67}$ later implemented useful changes in the country's medical structure, none of them can compare with Erskine's incredible range and diversity.

\section{SUMMARY}

The dominant part played by British doctors and apothecaries in the formation and development of Russian medicine and pharmacy is traced from 1581 to 1718. The trading privileges enjoyed by the Russia Company in return for providing war-beset Russia with a free outlet to the West through Archangel enabled them to supply the closely integrated Russian medico-apothecary system with the medicines and apothecary wares it needed. An attempt has been made at the same time to assess the extent to which members of the Society of Apothecaries of London promoted this commerce during Tsars Michael's and Alexis's reigns.

British doctors and apothecaries contributed significantly to all aspects of medicine in Russia, from the founding of the first Court Pharmacy to the establishment of the Apothecaries' Chancery in the new Russian capital of St Petersburg. They held the highest positions - Robert Erskine having supreme responsibility for the entire medical apparatus in Russia - built up the structure of medicine, formed medical libraries and collections, and developed apothecary gardens.

The multi-dimensional roles performed by British doctors in Russian society have also been emphasized.

\footnotetext{
64 John H. Appleby and Andrew Cunningham, 'Robert Erskine and Archibald Pitcairne - two Scottish physicians' outstanding libraries', Biblthk., 1982, 11: 3-16.

${ }^{65}$ Renate Burgess, 'Thomas Garvine. Ayrshire surgeon active in Russia and China', Med. Hist., 1975, 19: 91-94; Appleby, op. cit., note 34 above, pp. 86-95.

${ }^{66}$ Ibid., pp. 96-133.

${ }^{67}$ Ibid., pp. 154-184; John H. Appleby, " "Rhubarb" Mounsey and the Surinam toad - a Scottish physician-naturalist in Russia', Archs nat. Hist., [in press].
} 